\title{
Microstructural changes in casein supramolecules during acidification of skim milk
}

\author{
D. J. McMahon, ${ }^{1}$ H. Du, W. R. McManus, and K. M. Larsen \\ Western Dairy Center, Utah State University, Logan 84322
}

\section{ABSTRACT}

Pasteurized skim milk was acidified using different levels of glucono- $\delta$-lactone at $10,20,30$, and $40^{\circ} \mathrm{C}$ to give slow, medium, and fast rates of acidification. Milk coagulation was monitored by measuring turbidity and curd firmness, and microstructural changes during acidification were observed on glutaraldehyde-fixed, agar-solidified milk samples using transmission electron microscopy. Rate of acidification had little influence on changes observed during acidification, except at $10^{\circ} \mathrm{C}$. At $40^{\circ} \mathrm{C}$, the casein supramolecules were spherical throughout acidification, whereas at lower temperatures they became progressively more ragged in appearance. All of the milks gelled at the same $\mathrm{pH}(\mathrm{pH} 4.8)$, as measured by curd firmness, whereas increases in turbidity, assumed to be brought about by an increase in number of light-scattering particles, were observed to start at about $\mathrm{pH} 5.2$ to 5.4. As the milk was acidified, aggregates of loosely entangled proteins were observed, presumably originating from proteins that had dissociated from the casein supramolecules. These aggregates were often as large as the casein supramolecules, particularly as the $\mathrm{pH}$ of the milk approached the isoelectric point of the caseins. Larger aggregates were observed at $40^{\circ} \mathrm{C}$ than at the lower temperatures, suggesting the involvement of hydrophobic interactions between the proteins. A 3-phase model for acid-induced gelation of milk is proposed in which the first phase involves temperaturedependent dissociation of proteins from the casein supramolecules, with more dissociation occurring as temperature is decreased. Dissociation continues as milk $\mathrm{pH}$ is lowered, with the released proteins forming into loosely entangled aggregates, some as large as the casein supramolecules. The second phase of acid gelation of milk occurs between $\mathrm{pH} 5.3$ and $\mathrm{pH} 4.9$ and involves a reassociation of proteins with loosely entangled protein aggregates forming into more-compact colloidal particles or combining with any remaining casein supramolecules. The third and final phase involves rapid

Received April 24, 2009.

Accepted August 11, 2009.

${ }^{1}$ Corresponding author: donald.mcmahon@usu.edu aggregation of the colloidal casein supramolecules into a gel network at about $\mathrm{pH}$ 4.8. Different gel structures were formed based on temperature of acidification, with a coarse-stranded gel network formed at $40^{\circ} \mathrm{C}$ and a fine-stranded gel network at $10^{\circ} \mathrm{C}$.

Key words: milk coagulation, casein supramolecule, acid gelation

\section{INTRODUCTION}

Acid coagulation of milk is the foundation of many dairy products. It is well recognized that when $\mathrm{pH}$ of milk is sufficiently lowered and passes through the isoelectric point of the caseins, their solubility decreases, bringing about an association and subsequent coagulation (Kauzmann, 1959). Formation and physical properties of acid milk gels have been reviewed by Lucey and Singh (1998) and their rheological properties have been extensively studied (Lucey et al., 1998; Lucey, 2001; Tranchant et al., 2001), and mathematical models describing acid coagulation have been developed (Novakovic et al., 2000). Milk can be acidified and coagulated when warm (typically in the range of $30-45^{\circ} \mathrm{C}$ ) or it can be acidified while cold (e.g., $5^{\circ} \mathrm{C}$ ) and then warmed to induce gel formation. Traditionally, milk is acidified by microbial fermentation, but slow chemical acidification using glucono- $\delta$-lactone (GDL) is also used, such as in the manufacture of cottage cheese. Depending on the type of product being manufactured, the milk may or may not be given a high-heat treatment before acidification to denature $\beta$-lactoglobulin, which also then participates in the gelation process.

It has been observed that different gel properties are obtained based on acidification temperature (Lucey et al., 1997), such as excessive syneresis and a coarser gel texture occurring when the incubation temperature of yogurt is increased (Lucey, 2001). During acidification of milk, calcium phosphate contained in the casein supramolecules is solubilized (Evanhuis and de Vries, 1959; Visser et al., 1986) and proteins dissociate from the casein supramolecules (Roefs et al., 1985; van Hooydonk et al., 1986; Vreeman et al., 1989), although, as stated by Dalgleish et al. (2005), it has not been clearly established that lowering $\mathrm{pH}$ and solubilizing 
calcium phosphate alters the internal structure of the casein supramolecules. Such protein dissociation is temperature-dependent, with more casein becoming nonsedimentable at $5^{\circ} \mathrm{C}$ than at higher temperatures (Dalgleish and Law, 1988; Singh et al., 1996).

As milk is acidified there is a decrease in magnitude of net negative charge on both individual protein molecules and the overall net charge of casein supramolecules (Heertje et al., 1985), and solubilizing calcium phosphate causes the calcium phosphate nanoclusters that provide an interlocking aspect to the casein supramolecule (McMahon and Oommen, 2008) to be gradually depleted. Any proteins (such as some $\alpha_{\mathrm{S}^{-}}, \alpha_{\mathrm{S}^{-}}$, and $\beta$-casein) that are bound into the supramolecule structure only by the sequestering action of their phosphoserine groups toward the calcium phosphate can dissociate, especially if milk is cold and hydrophobic interactions are minimized.

Dalgleish and Law (1988) observed that at $30^{\circ} \mathrm{C}$, dissociation of casein upon acidification of milk to $\mathrm{pH} 5.5$ resulted in a constant proportion of $\alpha_{\mathrm{S1}^{-}}, \beta$-, and $\kappa$-casein, suggesting that these proteins may have dissociated as an intact complex. The small size of these particles also agrees with them being enriched in $\kappa$-casein and having less $\alpha_{S 1}$-casein than the original casein supramolecules. This would be expected because $\kappa$-casein is needed to stabilize the particles because neither $\beta$-casein nor $\alpha_{\mathrm{S}}$-caseins can exist as monomers under these conditions (van Hooydonk et al., 1986). At low temperature there is more dissociation of proteins from the casein supramolecules. Dalgleish and Law (1988) reported 30 and $55 \%$ being dissociated at 20 and $4^{\circ} \mathrm{C}$, respectively, whereas Singh et al. (1996) reported only 7 and $22 \%$ dissociation at 22 and $5^{\circ} \mathrm{C}$, respectively, probably because they used a higher centrifugal force $(88,000 \times g$ vs. $70,000 \times g)$, which would sediment more of the very small casein supramolecules and aggregates.

Maximum protein dissociation occurs at about $\mathrm{pH}$ 5.5. Then, as milk is further acidified, the amount of nonsedimentable casein decreases to zero at $\mathrm{pH} 4.8$, at which stage all of the casein is incorporated into the gelled network. In unheated milk, a slight decrease in casein supramolecule particle size has been observed and interpreted as a collapse of a hairy layer on the particle surface that then causes gelation (Dalgleish et al., 2005). The model of casein supramolecules proposed by McMahon and Oommen (2008) suggests that such decrease in particle size would result from a global contraction of the supramolecule rather than just the collapse of a hairy layer.

Various models of acid gelation of milk have been developed. Herbert et al. (1999) proposed a 2-phase process involving dissociation of proteins from the casein supramolecules and concomitant swelling of the casein micelles from $\mathrm{pH} 6.7$ to $\mathrm{pH} 5.1$, followed by reabsorption of protein back into the casein supramolecules and aggregation as $\mathrm{pH}$ falls below $\mathrm{pH}$ 5.1. Famelart et al. (2004) proposed that a swelling of the casein supramolecules occurs at about $\mathrm{pH} 5.2$, followed by their aggregation at about $\mathrm{pH} 5.0$ and then fusing together as the $\mathrm{pH}$ continues to decrease. Heertje et al. (1985) observed casein supramolecules in unheated milk at $20^{\circ} \mathrm{C}$ down to $\mathrm{pH} 5.2$ that were considered to be depleted of $\beta$-casein. Then, as renewed interaction of $\beta$-casein with other caseins occurs as the $\mathrm{pH}$ decreases below the isoelectric point of $\beta$-casein, aggregation of casein supramolecules was observed to commence by $\mathrm{pH}$ 5.1.

Even though acid-coagulated milk gels are observed as a network of aggregated colloidal casein supramolecules (Tamime et al., 1984), in all these models it is recognized that the supramolecular structure would change as protein dissociation and reassociation takes place and the charge distribution on the proteins change. At $\mathrm{pH} 4.8$, the protein molecules carry different charges than they do at the native neutral $\mathrm{pH}$ of milk, and so their conformational structure, as well as how they interact with each other, would be different. Less calcium bridging and ion-pairing will occur because they will carry fewer negatively charged AA side groups. The casein-casein interactions that do occur will result from hydrophobic liaisons (if the temperature is high enough) and a decrease in electrostatic repulsion. In comparison, during initial mammary gland synthesis of milk, a combination of hydrophobic liaisons and attractive interactions with calcium phosphate nanoclusters orients casein molecules in forming native casein supramolecules (McMahon and Oommen, 2008).

The focus of our paper was to observe the structural changes occurring in casein supramolecules and any related dissociation of protein from the supramolecular structure during acidification of unheated milk (i.e., milk that has not been heat-treated to bring about extensive denaturation and aggregation of whey proteins). This was performed at warm and cold conditions to determine the effect of temperature, as well as rate of acidification, on the gelation process to expand the current model to a wider set of conditions.

\section{MATERIALS AND METHODS}

\section{Preparation of Milk}

Raw whole cows' milk was obtained from the Gary Haight Richardson Dairy Products Laboratory of Utah State University (Logan), centrifuged (Sorvall RC-5C, Du Pont Company, Mississauga, Ontario, Canada) at $3,000 \times g$ for 60 min at $4^{\circ} \mathrm{C}$, and filtered through glass 
fiber filter paper under suction. The resultant skim milk was then given a minimal pasteurization treatment of $63^{\circ} \mathrm{C}$ for $30 \mathrm{~min}$. If the milk was to be chemically acidified, $0.02 \%$ (wt/wt) sodium azide (Mallinckrodt, Paris, KY), 0.01\% chloramphenicol (Sigma-Aldrich Co., St. Louis, MO), and $0.01 \%$ benzylpenicillin potassium salt (Sigma-Aldrich Co.) were added to inhibit bacteria growth. The milk was cooled to $4^{\circ} \mathrm{C}$ and stored overnight, and then warmed to the required temperature $\left(10,20,30\right.$, or $\left.40^{\circ} \mathrm{C}\right)$ and held for $30 \mathrm{~min}$ in a water bath.

\section{Milk Acidification}

Microbial acidification with $1.2 \mathrm{~g}$ of freeze-dried yogurt starter culture (Lactobacillus delbrueckii ssp. bulgaricus and Streptococcus thermophilus; Danisco USA, New Century, KS) per $100 \mathrm{~g}$ of skim milk at $40^{\circ} \mathrm{C}$ was used to lower the $\mathrm{pH}$ to 4.6 in $125 \mathrm{~min}$. Chemical acidification of milk was performed by addition of GDL (Sigma-Aldrich Co.) at levels of 2.0, 3.0, and $4.0 \mathrm{~g} / 100$ $\mathrm{g}$ at $10^{\circ} \mathrm{C} ; 2.0,2.5$, and $3.0 \mathrm{~g} / 100 \mathrm{~g}$ at 20 and $30^{\circ} \mathrm{C}$; and $1.5,2.0$, and $2.5 \mathrm{~g} / 100 \mathrm{~g}$ at $40^{\circ} \mathrm{C}$. The addition of $4.0,2.5,2.0$, and $1.5 \mathrm{~g}$ of GDL/100 g of milk at 10, 20, 30 , and $40^{\circ} \mathrm{C}$, respectively, produced acidification rates such that $\mathrm{pH} 4.6$ was reached in $125 \mathrm{~min}$.

\section{Electron Microscopy}

Before and during the acidification process, 5-mL samples were taken and fixed by the addition of 0.2 $\mathrm{mL}$ of a $50 \%$ glutaraldehyde solution (Electron Microscopy Sciences, Fort Washington, PA). After 5 min, the milk was solidified by mixing with an equal volume of warm $\left(50^{\circ} \mathrm{C}\right) 3 \%$ (wt/wt) agar (Bacto-Agar, Difco Laboratories, Detroit, MI). The samples were cut into small strips $(1 \times 1 \times 10 \mathrm{~mm})$ and preserved in $0.1 \mathrm{M}$ phosphate buffer solution, $\mathrm{pH} 6.8$, containing $2 \%$ (wt/ wt) glutaraldehyde and stored at $4^{\circ} \mathrm{C}$.

The glutaraldehyde-fixed, agar-solidified samples were reduced in size to $1-\mathrm{mm}^{3}$ cubes, rinsed with 0.1 $M$ phosphate buffer, and post-fixed in $2 \%$ (wt/wt) osmium tetroxide (Electron Microscopy Sciences) in the phosphate buffer. Dehydration was performed by transferring samples through an increasing concentration of graded ethanol $(30,50,70,95$, and 100\%). After dehydration, the samples were transitioned into propylene oxide and mixed in varying proportions ranging from $25 \%$ ethanol in propylene oxide to $100 \%$ propylene oxide alone in 4 steps. The cubes were infiltrated with a solution containing propylene oxide and epoxy resin (Electron Microscopy Sciences) stepwise in various proportions ranging from $25 \%$ propylene oxide in epoxy resin to $100 \%$ epoxy resin. The infiltrated samples were embedded in Beem capsules (Electron Microscopy Sciences) and incubated at $45^{\circ} \mathrm{C}$ followed by $60^{\circ} \mathrm{C}$ for $24 \mathrm{~h}$ each. The hardened epoxy resin was removed from the Beem capsule and excess epoxy was trimmed to expose the sample. Ultrathin sections were cut using an Ultracut E ultramicrotome (Leica Inc., Gilroy, CA) and collected on 300 hex grids (Electron Microscopy Sciences). Sections were post-stained with uranyl acetate and lead citrate and examined using a Zeiss CEM 902 transmission electron microscope (Zeiss Inc., Thornwood, NY) at $80 \mathrm{kV}$. Images were recorded on Kodak electron image film SO-163 (Eastman Kodak Co., Rochester, NY).

\section{Turbidity}

Turbidity changes brought about by changes in particle size, aggregation, and gelation were monitored using a single beam spectrophotometer (model DU-8B; Beckman Instruments Inc., Fullerton, CA) as described by McMahon et al. (1984). Milk was warmed to 10, 20, 30 , or $40^{\circ} \mathrm{C}$ for $30 \mathrm{~min}$, and a 3 -mL portion was poured into a 1-cm-pathlength cuvette and placed into the spectrophotometer. Turbidity of the milk (typically $>2$ absorbance units when measured at $600 \mathrm{~nm}$ ) was set to zero before acidification so that only the change in turbidity was recorded. This sample was then removed from the cuvette holder and, after appropriate amounts of GDL (or starter culture) had been added, aliquots of milk were poured into duplicate 3 -mL cuvettes, placed in the cuvette holder, and maintained at 10, 20, 30, or $40^{\circ} \mathrm{C}$. Changes in turbidity at $600 \mathrm{~nm}$ were then measured using one cuvette while the other was used to monitor changes in $\mathrm{pH}$ using a glass microelectrode (Microelectrodes Inc., Londonderry, NH). Measurements were performed in triplicate.

\section{Gelation}

The $\mathrm{pH}$ at which gelation occurred was determined in triplicate using a Formagraph (Dicky-John Corp., Fishkill, NY) with a modification of the method described by McMahon and Brown (1982). Milk was warmed to the appropriate temperature $\left(10,20,30\right.$, or $\left.40^{\circ} \mathrm{C}\right)$ for 30 min and the Formagraph 10-well sample holder was set to the same temperatures. For each temperature, the required amount of GDL or starter culture was added to the milk at the same time that the Formagraph recorder module was started. About $10 \mathrm{~mL}$ of milk was then deposited in each sample well and the sample holder transferred to the recorder module. Detection of curd formation was defined as the point where the baseline of firmness versus time diagram began to increase in width. Changes in $\mathrm{pH}$ of the milk samples were recorded using a glass microelectrode. 

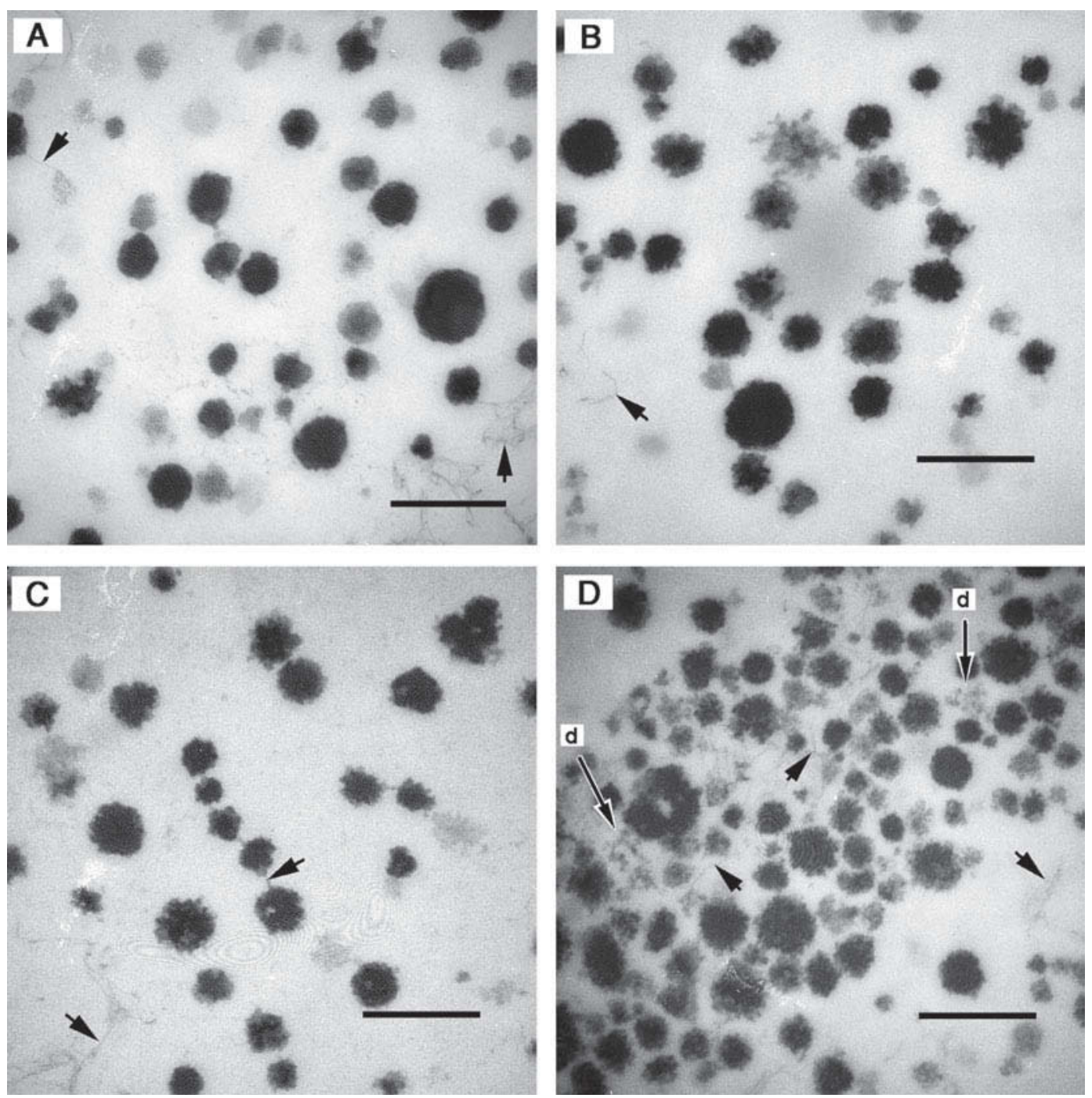

Figure 1. Transmission electron micrographs of skim milk, glutaraldehyde-fixed and agar-solidified at $(\mathrm{A}) 40^{\circ} \mathrm{C},(\mathrm{B}) 30^{\circ} \mathrm{C},(\mathrm{C}) 20^{\circ} \mathrm{C}$, and $(\mathrm{D})$ $10^{\circ} \mathrm{C}$ (short arrows $=$ agarose fibers; $\mathrm{d}=$ dissociated protein; bar $=500 \mathrm{~nm}$ ).

\section{RESULTS}

\section{Prior to Acidification}

The measured $\mathrm{pH}$ of the milks at $10,20,30$, and $40^{\circ} \mathrm{C}$ was $\mathrm{pH} 6.96,6.75,6.64$, and 6.55 , respectively. This shift in $\mathrm{pH}$ as milk is cooled is related to uptake of protons as calcium phosphate present in nanoclusters in the casein supramolecule is solubilized upon cooling and their release when milk is warmed and calcium phosphate precipitates. The microstructure of the casein supramolecules that was observed (Figure 1) was similar to that which has long been reported using transmission electron microscopy to examine glutaraldehyde-fixed milk (e.g., Kalab et al., 1976). Other methods of imaging casein supramolecules (McMahon and McManus, 1998; McMahon and Oommen, 2008) have shown that casein supramolecules have a more open structure than previously observed. However, to capture the spatial arrangement of protein aggregates during acidification but before gelation, we solidified the milk by mixing it with agar, which necessitated that we first fixed the proteins with glutaraldehyde. There were strong interactions between the casein supramolecules and agar that caused structural artifacts if acidified milk was mixed with the warm agar without prior glutaraldehyde fixation (data not shown). Strands of protein that appeared to radiate from the casein supramolecules were observed in nonglutaraldehyde-fixed acidified milks similar to those observed by Kalab et al. (1976). Thus, whereas the fine internal supramolecular structure of the casein supramolecules could not be retained, the dissociation of material from the casein supramolecules that occurred 
when milk was cooled or acidified could be observed. Thin, fibrous strands observed in the micrographs were designated as artifacts relating to solidifying the milk in agar and were assumed to be agarose fibers (Alleyne et al., 1993).

At $40^{\circ} \mathrm{C}$, the casein supramolecules were observed to have predominantly smooth spherical surfaces and had a range of sizes. There appeared to be very few casein supramolecules $<80 \mathrm{~nm}$ in diameter. Some casein supramolecules had appendages, but the majority of the electron-dense areas in the micrographs were the colloidal casein supramolecules, with little nonparticulate protein being observed (Figure 1A). Individual protein molecules and small oligomers are too small to be observed against the micrograph background or retained in the samples during sample preparation, and so whey proteins present in the original milks were not observed in the micrographs. At lower temperatures there appeared to be more electron dense-material that was only loosely attached to the casein supramolecules with no extensive dissociation of the casein supramolecules, except for milk at $10^{\circ} \mathrm{C}$.

At $30^{\circ} \mathrm{C}$ (Figure 1B), the casein supramolecules were spherical but many of them had surface protuberances similar to that reported using scanning electron microscopy (Kalab et al., 1982; Dalgleish et al., 2004b). In some cases, the surface material seemed only loosely attached to the rest of the colloidal particle. At $20^{\circ} \mathrm{C}$ (Figure 1C), the casein supramolecule surface had a more tendrillar appearance, with electron-dense areas protruding from the particle surface.

At $10^{\circ} \mathrm{C}$ (Figure 1D), the casein supramolecules appeared close together and grouped in clumps; however, this was attributed to rapid solidification of the warm agar before it could be well dispersed throughout the cold milk. The casein supramolecules had a more ragged structure and there was a greater proportion of smaller particles, including some that were no longer spherical in appearance. Also, there were some particles that had an absence of material in their core. Compared with casein supramolecules at $40^{\circ} \mathrm{C}$, the casein supramolecules at $10^{\circ} \mathrm{C}$ were less electron-dense (i.e., there was less heavy-metal staining) and their peripheral edges were less distinct with a relatively open structure. There was also more protein material dispersed as loose aggregates among the casein supramolecules at $10^{\circ} \mathrm{C}$ than at higher temperatures.

\section{Acidification Rate}

Microbial acidification of milk at $40^{\circ} \mathrm{C}$ using starter culture began slowly (apart from a small decrease caused by adding the starter culture itself). After approximately $15 \mathrm{~min}$ the rate increased as the starter

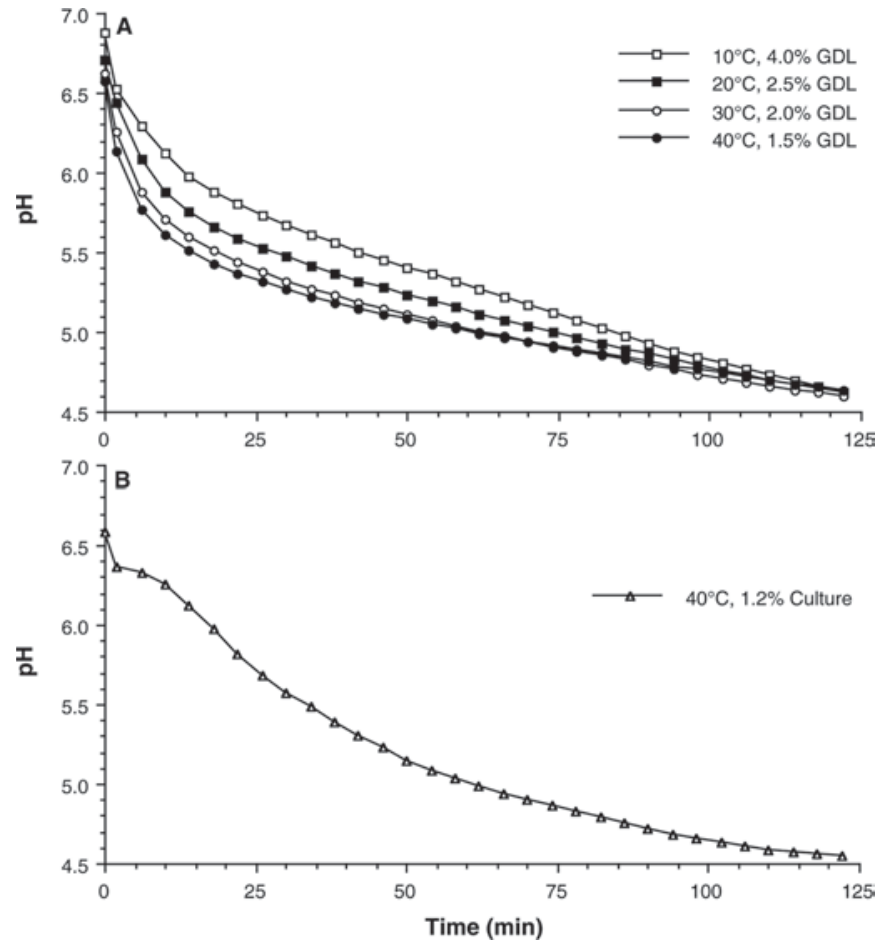

Figure 2. Reduction of $\mathrm{pH}$ in skim milk as a function of temperature based on (A) amount of glucono- $\delta$-lactone (GDL) added and (B) addition of $1.2 \%$ freeze-dried starter culture.

culture moved into log phase and begin to multiply, generating lactic acid (Figure $2 \mathrm{~A}$ ). Then the $\mathrm{pH}$ gradually decreased, with a $\mathrm{pH}$ of 4.6 being reached after 125 min. In contrast, during chemical acidification there was an initial rapid decrease in $\mathrm{pH}$ as GDL was hydrolyzed to gluconic acid, then acidification rate slowed as the concentration of remaining GDL decreased (Figure $2 \mathrm{~B})$.

\section{Microstructure of Warm Acidified Milk}

GDL-Acidified Milk. In $40^{\circ} \mathrm{C}$ milk, microstructural changes in the casein supramolecule structure were observed during acidification by GDL (Figure 3). At $\mathrm{pH} 5.5$ (Figure 3A) there were numerous small casein supramolecules, many as small as $30 \mathrm{~nm}$ in diameter. Casein supramolecules up to $200 \mathrm{~nm}$ diameter were still present, although on a number basis the smaller casein supramolecules were predominant. There were no protuberances on the periphery of the casein supramolecules, which appear more spherical than before acidification. As acidification continued to $\mathrm{pH} 5.2$ (Figure $3 \mathrm{~B})$, the very small casein supramolecules (30-40 $\mathrm{nm}$ diameter) were no longer present, being replaced by loosely entangled proteins dispersed among the larger spherical casein supramolecules. Some of these loosely 

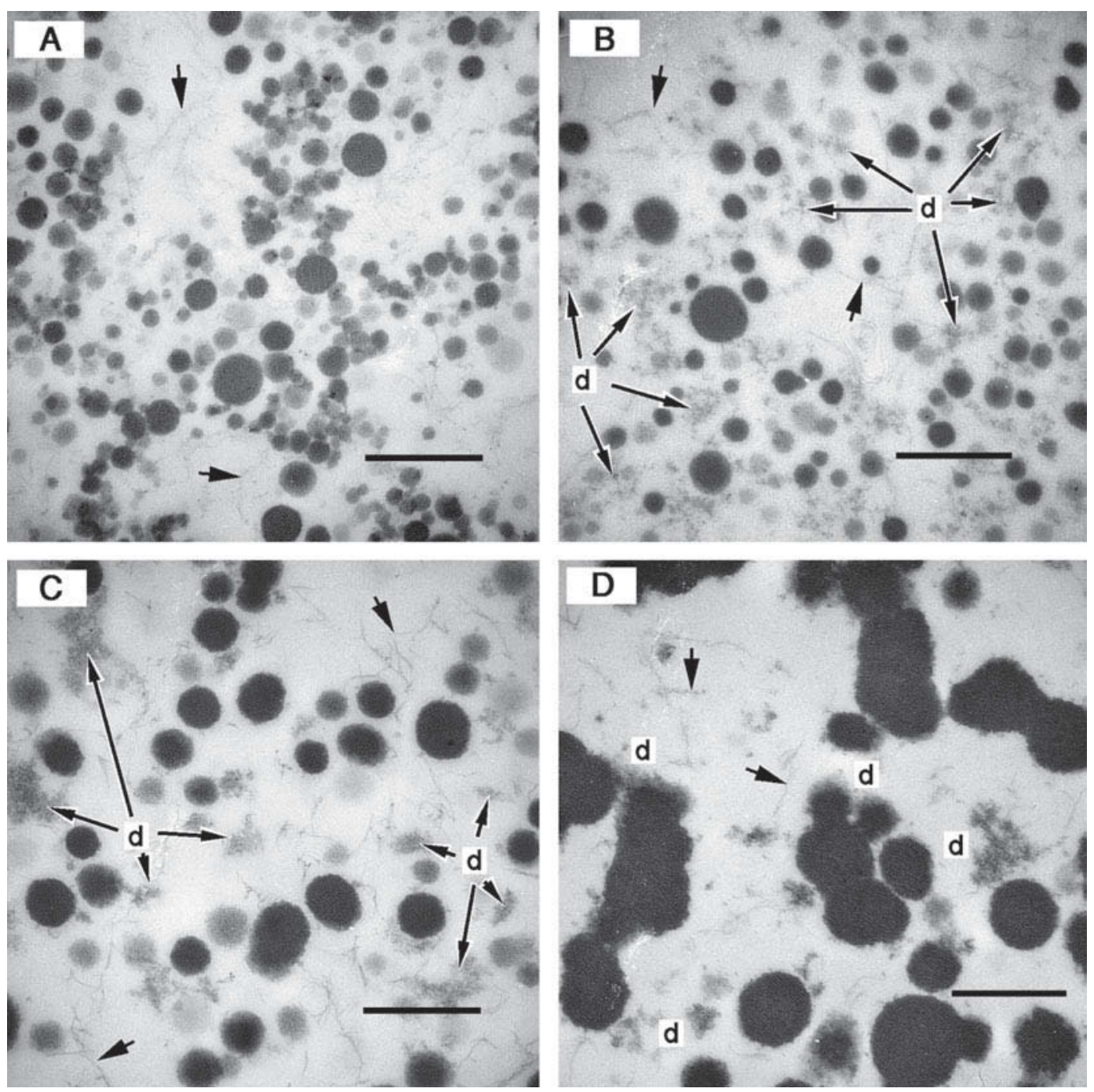

Figure 3. Transmission electron micrographs during warm acidification at $40^{\circ} \mathrm{C}$ of skim milk by $1.5 \%$ glucono- $\delta$-lactone, glutaraldehyde-fixed and agar-solidified at (A) $\mathrm{pH} 5.5,(\mathrm{~B}) \mathrm{pH} 5.2,(\mathrm{C}) \mathrm{pH} 4.95$, and (D) $\mathrm{pH} 4.8(\mathrm{~d}=$ loosely entangled protein; short arrows = agarose fibers; bar $=500 \mathrm{~nm})$.

entangled proteins were present in clumps of up to 100 to $200 \mathrm{~nm}$ in size.

At pH 4.95 (Figure 3C), the dissolution of the casein supramolecules continued, with only casein supramolecules $>100 \mathrm{~nm}$ in diameter remaining. Casein supramolecules were present that had only low electron density (gray spherical particles) and were mainly in the size range of 100 to $200 \mathrm{~nm}$ diameter. Larger, denser casein supramolecules (black spherical particles) were also present, ranging from 150 to $250 \mathrm{~nm}$ in diameter. In addition to the spherical casein supramolecules there were clumps of loosely entangled protein dispersed throughout the sample. Compared with the milk at $\mathrm{pH}$ 5.2 , this loosely entangled protein at $\mathrm{pH} 4.95$ tended to be present as very low electron density particle-like aggregates.
When the $40^{\circ} \mathrm{C}$ milk had been acidified to $\mathrm{pH} 4.8$ (Figure 3d), the casein protein appeared as an interconnecting colloidal mass, indicative of a 3-dimensional gel network being formed. When using transmission electron microscopy to examine thin sections of a gel, only a cross-sectional view is obtained, which underestimates the extent of strand formation that makes up the gel network (Kalab et al., 1976). Even what appears to be individual colloidal particles would most likely be a cross-section of a strand that is traversing the thin section at a perpendicular angle. The strands of the gel network appeared to be about 180 to $300 \mathrm{~nm}$ in thickness. Some clumps of loosely entangled protein were also evident, but the majority of this protein had become associated with the casein supramolecules and could be observed as filamentous material on the pe- 

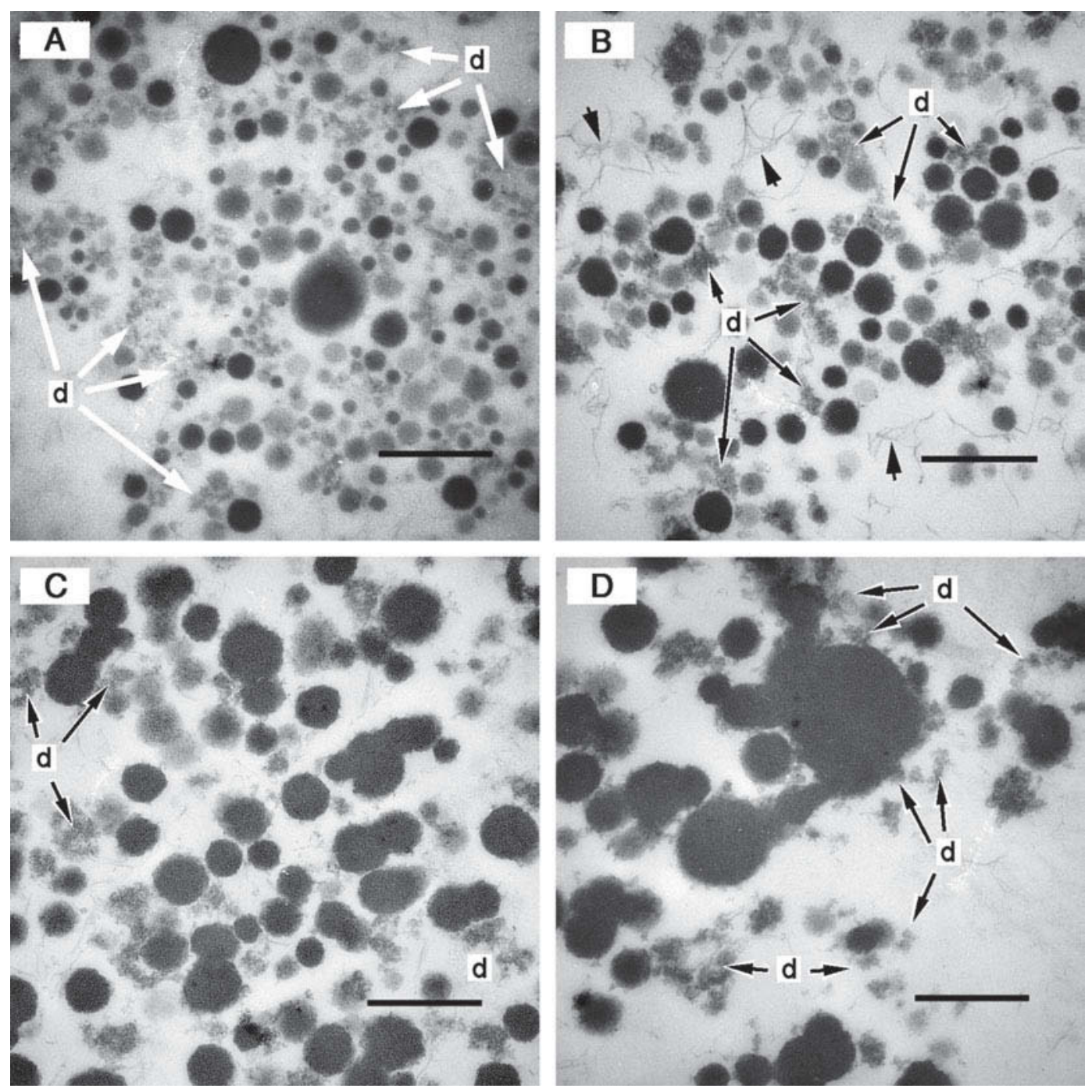

Figure 4. Transmission electron micrographs during warm acidification at $40^{\circ} \mathrm{C}$ of skim milk by addition of $1.2 \%$ starter culture, glutaraldehyde-fixed and agar-solidified at (A) $\mathrm{pH} 5.4,(\mathrm{~B}) \mathrm{pH} 5.0,(\mathrm{C}) \mathrm{pH} 4.75$, and $(\mathrm{D}) \mathrm{pH} 4.6$ (d = loosely entangled protein; short arrows = agarose fibers; bar $=500 \mathrm{~nm}$ ).

riphery of the gel network strands. Heertje et al. (1985) had observed that in warm acidified milk, the coagulum that formed consisted of clusters of aggregated micelles that had joined together to form a 3-dimensional network.

Microbially Acidified Milk. Changes in microstructure during microbial acidification of warm milk (Figure 4) were similar to that observed when using GDL (Figure 3). The only difference was that dissociated of protein from the casein supramolecules seemed to occur earlier. By pH 5.4 (Figure 4A), there was an increase in number of small (40-60 nm diameter) casein supramolecules and a considerable amount of loosely entangled protein (whereas in the GDL-acidified milk this was not apparent until pH 5.2). At pH 5.0 (Figure 4B), there were no longer any intact casein supramolecules $<70 \mathrm{~nm}$ diameter. As was observed with GDL-acidified milk, the smaller casein supramolecules tended to be less electron-dense than the larger casein supramolecules. The loosely entangled protein was more interconnected than was observed at higher $\mathrm{pH}$.

Formation of large network strands was slightly delayed, although by $\mathrm{pH} 4.75$ considerable reassociation had occurred with virtually no colloidal particles being less than $100 \mathrm{~nm}$ diameter, with some clumps of loosely entangled proteins still present. The large network strands developed upon further acidification with the gel network formed (Figure 4D), being similar in appearance to the gel formed in warm GDL-acidified milk (Figure 3D). The loosely entangled protein and 

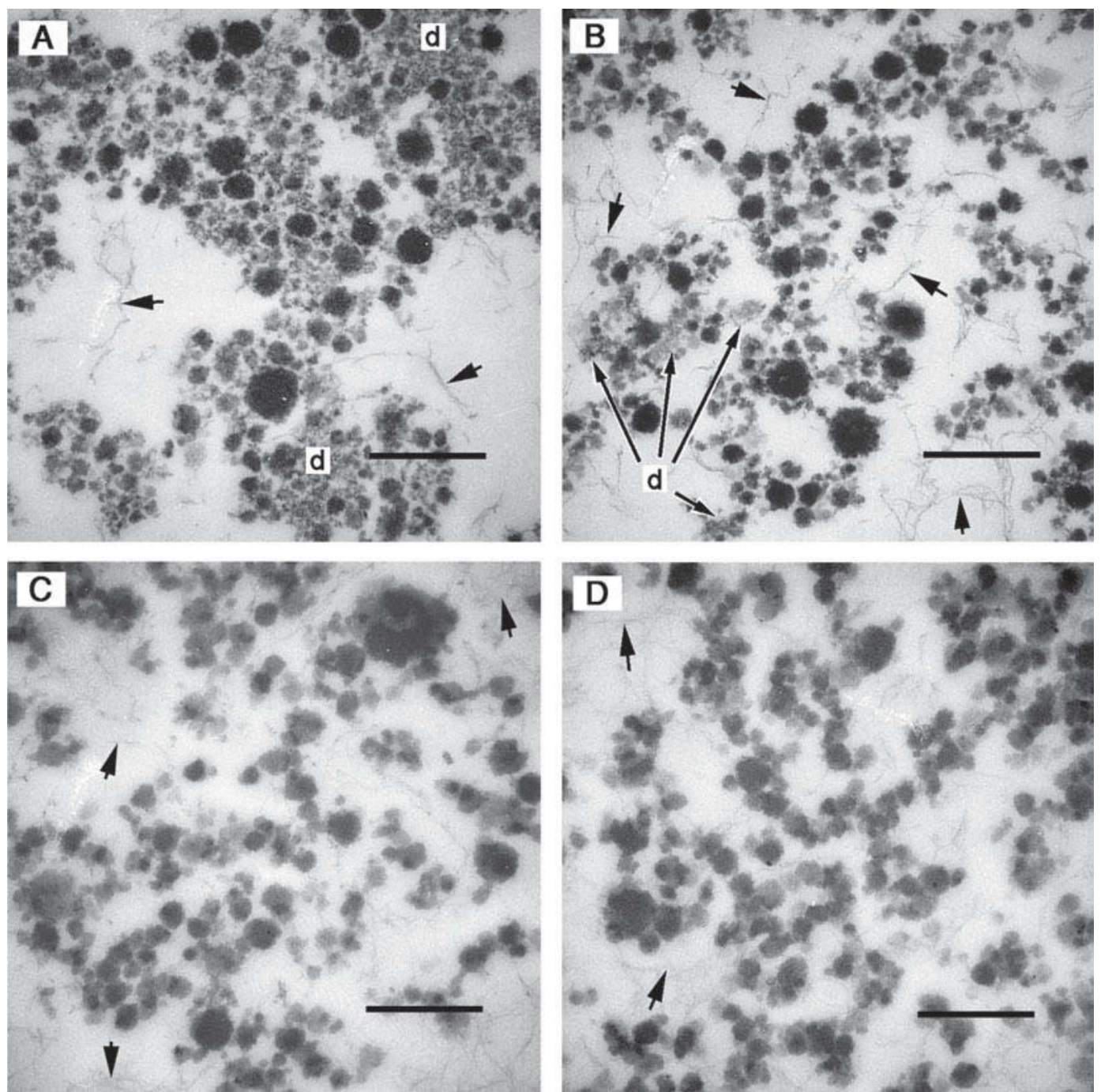

Figure 5. Transmission electron micrographs during cold acidification at $10^{\circ} \mathrm{C}$ of skim milk by $4.0 \%$ glucono- $\delta$-lactone, glutaraldehyde-fixed and agar-solidified at (A) $\mathrm{pH} 5.9,(\mathrm{~B}) \mathrm{pH} 5.3,(\mathrm{C}) \mathrm{pH} 5.0$, and $(\mathrm{D}) \mathrm{pH} 4.8(\mathrm{~d}=$ loosely entangled protein; short arrows = agarose fibers; bar $=$ $500 \mathrm{~nm})$.

the smaller casein supramolecules present at this $\mathrm{pH}$ were observed mostly to be fused to the periphery of the strands making up the gel network.

\section{Microstructure of Cold Acidified Milk}

When cold $\left(10^{\circ} \mathrm{C}\right)$ milk was acidified, there was a large increase in the amount of loosely entangled protein present, even at pH 5.9 (Figure 5A). The same artifact described above for addition of warm agar to cold milk samples was also present in the micrographs, with the agar solidifying before complete mixing with the milk. Increased dissociation of the casein supramolecules was not unexpected because there was more dissociation observed in cold milk before acidification. At $\mathrm{pH} 5.3$ the proportion of loosely entangled protein appeared to have decreased (Figure 5B), suggesting that a reas- sociation of proteins back into colloidal particles had already commenced.

Cold acidified milk at pH 5.0 (Figure 5C) was similar to that at $\mathrm{pH} 5.3$, with the colloidal particles having numerous appendages on their peripheral surface with some small chains and clumps of particles. At $\mathrm{pH} 4.8$ (Figure 5D), virtually all the protein had become associated back into spherical particulate form and incorporated into a fine-stranded gel network. There was no evidence of the very large and electron-dense colloidal particles observed when cooled milk was acid coagulated. Differences in size of the colloidal particles forming the aggregated protein network as temperature was lowered to $\mathrm{pH} 4.8$ were more obvious when the gelled milks were examined at lower magnification (Figure 6). When coagulated at 10 and $20^{\circ} \mathrm{C}$, the gel network was made up of strands of aggregated colloidal particles that 

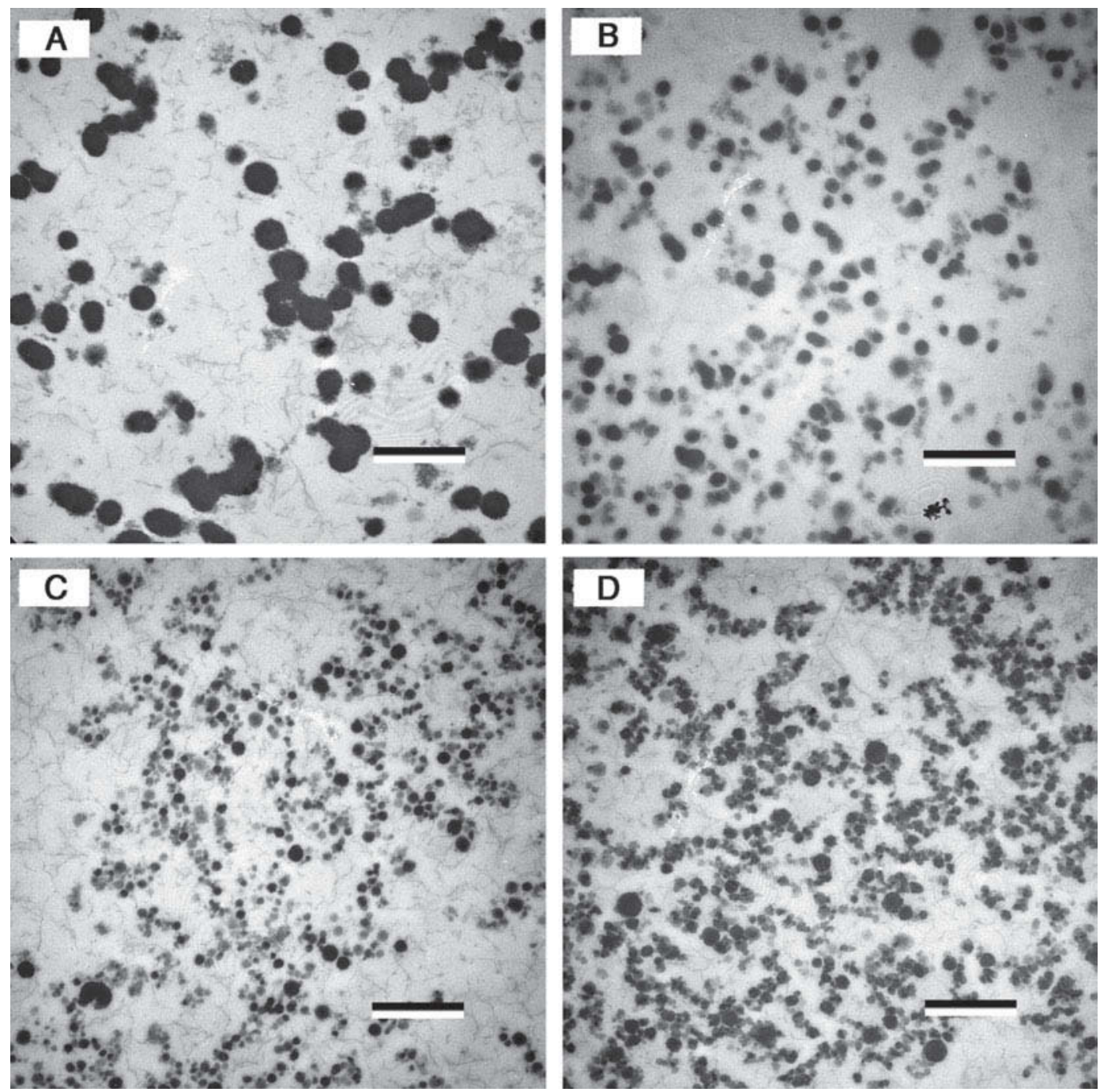

Figure 6. Transmission electron micrographs of acid milk gels at $\mathrm{pH} 4.8$ formed after acidification of skim milk by glucono- $\delta$-lactone at (A) $40^{\circ} \mathrm{C},(\mathrm{B}) 30^{\circ} \mathrm{C},(\mathrm{C}) 20^{\circ} \mathrm{C}$, and $(\mathrm{D}) 10^{\circ} \mathrm{C}($ bar $=1 \mu \mathrm{m})$.

were mostly $100 \mathrm{~nm}$ or less in diameter. At $30^{\circ} \mathrm{C}$ the colloidal particles of the network strands were slightly larger and about 100 to $200 \mathrm{~nm}$ diameter, whereas at $40^{\circ} \mathrm{C}$ they were in the range of 300 to $400 \mathrm{~nm}$ diameter. Similarly, the spacing between the network strands decreased as temperature was lowered, with spacings of 1 to $2 \mu \mathrm{m}$ regularly occurring at $40^{\circ} \mathrm{C}$ and spacings of a few hundred nanometers at 10 and $20^{\circ} \mathrm{C}$. At the lower temperatures the network strands appeared to be made of clusters of small particles rather than being a single linear strand as implied by the cross-sectional view of the gel network at $40^{\circ} \mathrm{C}$.

\section{Turbidity}

Although none of the treated milks formed a firm coagulum until $\mathrm{pH} 4.8$, changes taking place as described above were also detected by monitoring turbidity (Fig- ures 7 and 8 ). For warm milk ( 30 and $40^{\circ} \mathrm{C}$ ) the turbidity remained constant down to $\mathrm{pH} 6.2$, after which turbidity gradually increased by approximately 0.02 absorbance units. This was followed by a rapid turbidity increase at $\mathrm{pH} 5.3$ and 5.5, respectively (Figure 7 ). In contrast, for cooler milk $\left(10\right.$ and $20^{\circ} \mathrm{C}$ ) the increase in turbidity commenced sooner at approximately $\mathrm{pH} 6.5$ and followed the same general pattern as above, continuing to a maximum at $\mathrm{pH} 5.9$ and 5.6, respectively.

Directly after acidification, increase in turbidity was more pronounced at $10^{\circ} \mathrm{C}$. As acidification proceeded, the turbidity at $10^{\circ} \mathrm{C}$ decreased below its original level with a minimum occurring at about pH 5.3 (Figure 7). The depth of this turbidity minimum in the $10^{\circ} \mathrm{C}$ milk was larger if the acidification rate was slower (Figure 8a). No such turbidity decrease was seen for the other temperatures (data not shown). After further acidifica- 


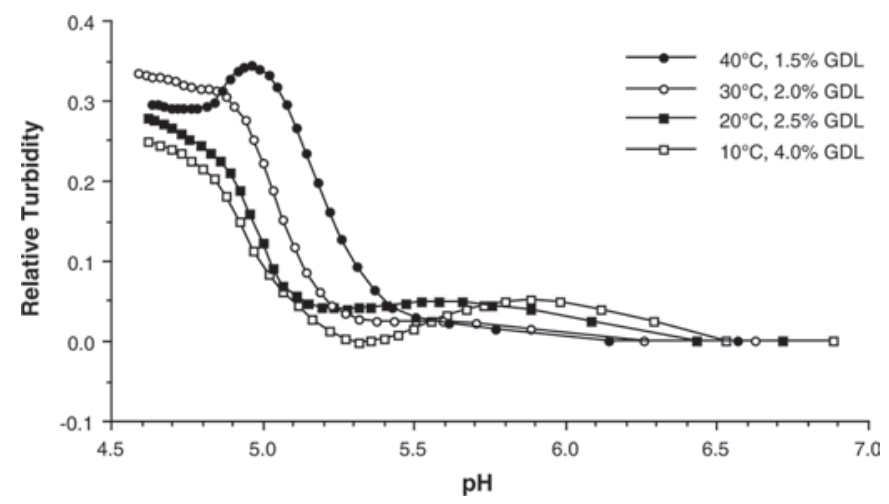

Figure 7. Influence of temperature on changes in turbidity upon acidification of skim milk by $4.0 \%, 2.5 \%, 2.0 \%$, and $1.5 \%$ (wt/wt) glucono- $\delta$-lactone (GDL) at $10,20,30$, and $40^{\circ} \mathrm{C}$, respectively.

tion, a rapid increase in turbidity was observed in all samples. At $40^{\circ} \mathrm{C}$, after this increase the turbidity decreased from its maximum, starting at $\mathrm{pH} 5.0$ and leveling off at $\mathrm{pH}$ 4.8. Similar changes in turbidity of warm milk during acidification had earlier been reported by Bringe and Kinsella (1990) at $25^{\circ} \mathrm{C}$, and Banon and Hardy $(1991,1992)$ at 30 and $42^{\circ} \mathrm{C}$. Recently, Alexander and Dalgleish (2004) and Dalgleish et al. (2004a), using diffusing wave spectroscopy to monitor GDL acidification of $30^{\circ} \mathrm{C}$ milk, reported changes in inverse photon free path $\left(1 / l^{*}\right)$ of unheated milk that had the same profile as our turbidity measurements. The value for $1 / l^{*}$ stayed virtually constant until $\mathrm{pH} 5.5$ and then rapidly increased before an increase in particle radius occurred at $\mathrm{pH} 5.0$, at which point a decrease in $1 / l^{*}$ occurred before reaching a steady value, as we observed with turbidity. The change that occurs before gelation is that the average distance between light-scattering events (i.e., $l^{*}$ ) decreases, implying that the number of colloidal particles increases (Alexander and Dalgleish, 2004).

If the inflection point of the turbidity curve is used as a measure of the $\mathrm{pH}$ at which the increase in particle number increases, then such an increase occurred at a higher $\mathrm{pH}$ as temperature was increased. The average turbidity inflection point for milks acidified using GDL was calculated at $\mathrm{pH} 4.96,4.98,5.05$, and 5.20 at 10 , 20, 30, and $40^{\circ} \mathrm{C}$, respectively. Kim and Kinsella (1989) similarly observed that turbidity changes during acidification of pasteurized skim milk started between $\mathrm{pH} 5.1$ and 5.2 at 35 to $50^{\circ} \mathrm{C}$ and increased to $\mathrm{pH} 5.6$ at $55^{\circ} \mathrm{C}$. The $\mathrm{pH}$ at which turbidity increased was not influenced by acidification rate at any of the temperatures (Figure 8A). Similar observations were made by Alexander and Dalgleish (2004), who observed that changes in apparent particle size during acidification of skim milk (at $30^{\circ} \mathrm{C}$ ) were dependent on the $\mathrm{pH}$ of the milk, with a sharp increase in apparent radius occurring at pH 5.0.
When milk at $40^{\circ} \mathrm{C}$ was acidified using starter culture, similar turbidity changes were observed except that, starting at $\mathrm{pH} 5.5$, the rate at which turbidity increased was slower (Figure 3B). Thus, the turbidity infection point occurred at $\mathrm{pH} 5.0$ rather than $\mathrm{pH} 5.2$ when the milk was acidified using GDL (Figure 8B), even though gelation $\mathrm{pH}$ as determined by measuring curd firmness was the same for both.

\section{DISCUSSION}

If the casein supramolecules in milk at $40^{\circ} \mathrm{C}$ before $\mathrm{pH}$ adjustment are considered to be in their native supramolecular form, then at lower temperatures or at lower $\mathrm{pH}$ they should be considered as having a nonnative structure. In general, this is seen as an increase in the number of small colloidal particles and the presence of loosely formed, nonspherical protein aggregates. Throughout the acidification process, differences in size and physical form of the casein supramolecules and aggregates occur depending on temperature (through its influence on hydrophobic interactions) and $\mathrm{pH}$ (through its influence on protein charge and calcium phosphate solubility). However, the actual physical gelation of the milk appears to override these differences because gelation occurs at the same $\mathrm{pH}(\mathrm{pH} 4.8)$ at all
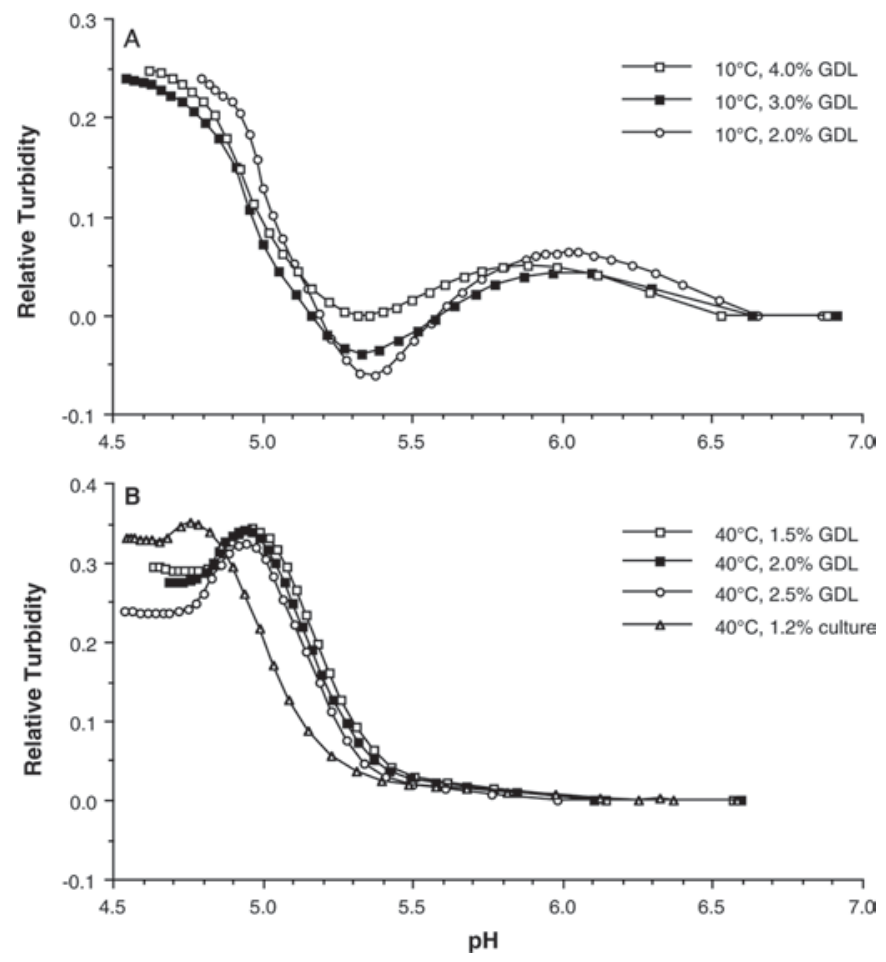

Figure 8. Change in turbidity of skim milk as a function of slow, medium, and fast acidification rates using glucono- $\delta$-lactone (GDL) at (A) $10^{\circ} \mathrm{C}$ and (B) $40^{\circ} \mathrm{C}$, as well as by using $1.2 \%$ starter culture at $40^{\circ} \mathrm{C}(\mathrm{B})$. 

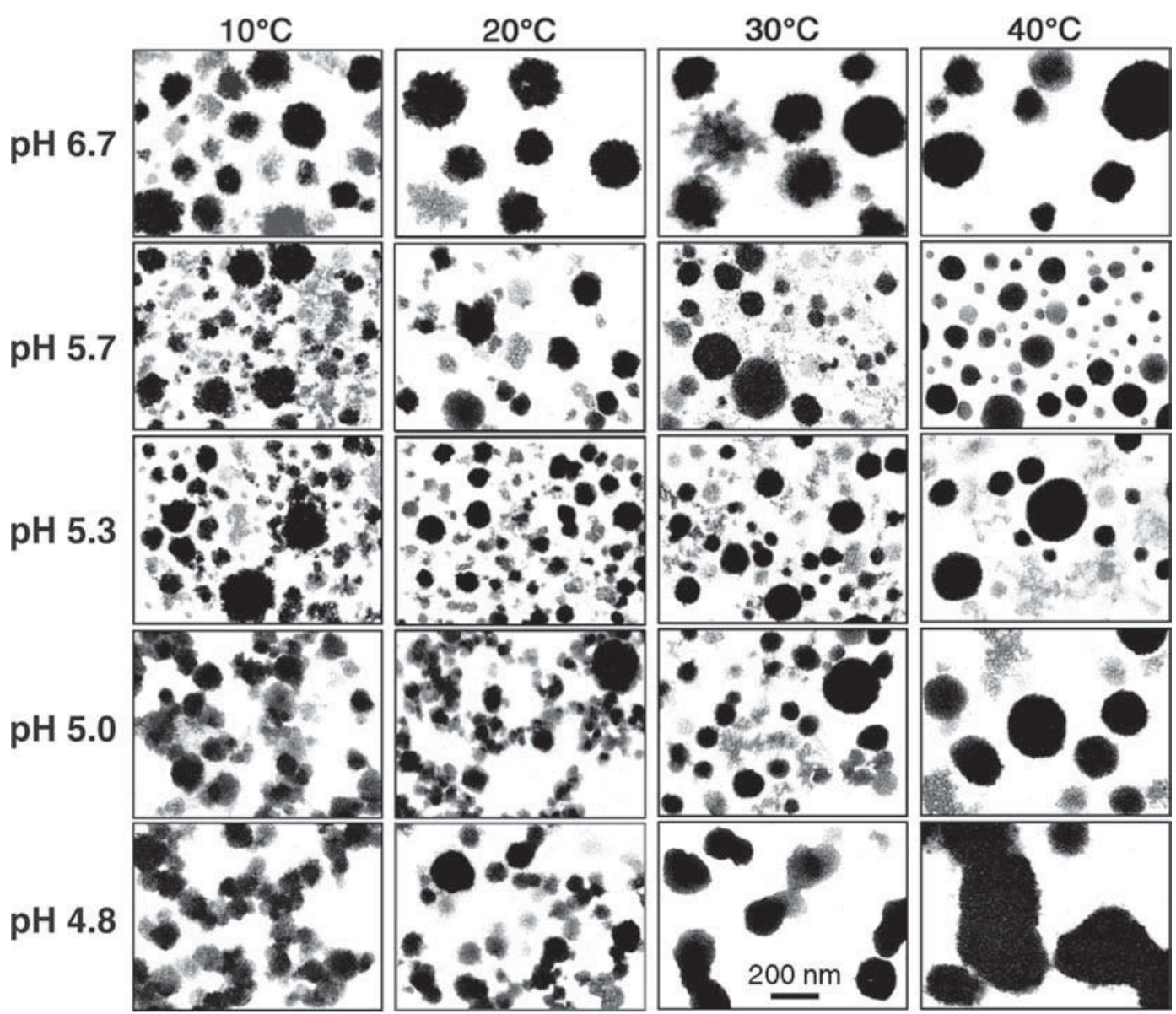

Figure 9. Microstructural changes occurring during chemical acidification of milk as a function of temperature and $\mathrm{pH}$. Images derived from transmission electron micrographs, with colloidal casein supramolecules depicted in black and loosely entangled protein aggregates depicted in gray, and all background digitally converted to white.

temperatures tested, regardless of the differences in the gel networks.

\section{Temperature-Induced Changes}

Reducing hydrophobic interactions by lowering temperature allows some casein molecules (especially $\beta$-casein), calcium, and phosphate to dissociate from the supramolecules (Qvist, 1979; Pierre and Brule, 1981; Dalgleish and Law, 1989) and for the caseins to be less tightly bound to each other. This appears to bring about loosening of the supramolecular structure as milk temperature is lowered from 40 to $20^{\circ} \mathrm{C}$. At $10^{\circ} \mathrm{C}$, a large number of smaller, less electron-dense and loosely entangled protein particles are present. When the micrographs were digitally modified through pixel binning to remove artifacts caused by agar solidification of the milk during sample preparation, to show only electron-dense casein supramolecules (black) and less electron-dense (gray) entangled protein aggregates (Figure 9), these changes become more apparent.

At $40^{\circ} \mathrm{C}$ (which is the closest temperature to their native state), most of the casein supramolecules were spherical and electron-dense, whereas at $10^{\circ} \mathrm{C}$ they were smaller, more ragged in appearance, and less electron-dense. The casein proteins were still predominantly present as colloidal particles, although some had tendrils and appendages extending from the particle periphery. This would be expected as Dalgleish and Law (1988) showed that as milk is cooled from 30 to $5{ }^{\circ} \mathrm{C}$, the fraction of caseins (or casein aggregates) that are too small to sediment at $70,000 \times g$ increases only slightly, from 5 to $13 \%$. This temperature-dependent difference of casein supramolecules needs to be taken into account when developing a model of acid-induced gelation of milk, as well as the differences in lightscattering properties of the loosely entangled protein aggregates compared with the intact supramolecules. 


\section{Acid-Induced Changes}

Dissociation of Protein from Casein Supramolecules. The first phase of acid gelation of milk involves a temperature-dependent dissociation of proteins from the casein supramolecules with less protein being released when the milk is warm $\left(40^{\circ} \mathrm{C}\right)$. At low temperatures (e.g., $\left.10^{\circ} \mathrm{C}\right)$, the dissociated proteins can be present as loosely entangled aggregates. At $40^{\circ} \mathrm{C}$, there appears to be sufficient hydrophobic interactions to maintain the proteins as (small) spherical colloidal particles (many with diameters $<50 \mathrm{~nm}$ ) as shown in Figure 9. This hydrophobic interaction would require a rearrangement and consolidation of the supramolecule interior structure with a predominance of $\kappa$-casein remaining on their periphery. Casein molecules can also be bound into the supramolecule structure via Ca-mediated salt bridges between carboxyl or phosphoserine side groups. These would remain so until the negative charge of the proteins is neutralized as $\mathrm{pH}$ is lowered. About $3.5 \mathrm{mM}$ of calcium in milk is directly bound to the caseins (Singh et al., 1996) and this represents an average of $3 \mathrm{Ca}^{++}$ions bound per protein molecule.

As pH is lowered, some loosely entangled, nonspherical aggregates were observed to be as large as the native casein supramolecules. Therefore, even though average particle size has been reported to remain relatively constant until the rapid aggregation stage (Singh et al., 1996; Dalgleish et al., 2004a), there are major changes taking place to the casein supramolecule particles and it does not appear that the structural framework of the casein supramolecules is maintained as earlier postulated. As shown in Figure 9, at $40^{\circ} \mathrm{C}$ there appears to be a decrease in size of the casein supramolecules, with many more small casein supramolecules being present at $\mathrm{pH}$ 5.7. This corresponds to the $\mathrm{pH}$ at which Dalgleish and Law (1988) observed maximum dissociation of casein from the supramolecules at $30^{\circ} \mathrm{C}$. However, the quantity of dissociated casein at $30^{\circ} \mathrm{C}$ they measured was still less than $10 \%$ of the total casein in milk, which supports our observation that at $30^{\circ} \mathrm{C}$ there are loosely entangled protein aggregates present at $\mathrm{pH} 5.7$ as well as many casein supramolecules in the 50 to 100 $\mathrm{nm}$ range. At $40^{\circ} \mathrm{C}$ and this $\mathrm{pH}$, the loosely entangled protein aggregates were not evident but there were many very small casein supramolecules in the 30 to 50 nm range.

It was apparent from our microstructural observations that, even at temperatures above $25^{\circ} \mathrm{C}$, there was dissociation of proteins from the casein supramolecules during acidification, but the dissociated proteins also existed in an aggregate or particulate form that would allow them to sediment during centrifugation. Thus, between $\mathrm{pH} 6.7$ and $\mathrm{pH} 5.5$ the dominant influences on protein dissociation are hydrophobic effects (temperature dependent) and calcium phosphate solubilization (which is both $\mathrm{pH}$ and temperature dependent).

Loosely Entangled Protein Aggregates. As further acidification occurs, there is more dissociation of proteins that appear to form into large, loosely entangled protein aggregates. Such aggregates are nonspherical and do not have the compact nature observed for casein supramolecules, although some are as large as the casein supramolecules and occasionally are attached to the casein supramolecules. The second phase of acid gelation occurs between about $\mathrm{pH} 5.3$ and $\mathrm{pH}$ 4.9 and involves these loosely entangled proteins forming into more compact colloidal particles. At $40^{\circ} \mathrm{C}$, the loosely entangled aggregates become quite large (up to 200-300 nm), whereas at $10^{\circ} \mathrm{C}$ they are much smaller and have already started to reassociate with the casein supramolecule remnants. As $\beta$-casein develops a net positive charge in this $\mathrm{pH}$ region it can act as a polymerizing agent with the negatively charged $\alpha_{S 1^{-}}$and $\alpha_{S 2}$-caseins.

This dissociated material was prevalent in the $10^{\circ} \mathrm{C}$ milk before and during the initial acidification and could account for the observed turbidity increase in cold milk (Figure 6), especially with slower acidification rates (Figure 7) that would allow more time for dissociation to occur. At cold temperatures, the dissociation of $\alpha_{\mathrm{S}^{-}}$, $\beta$-, and $\kappa$-caseins from casein supramolecules are independent of each other and, down to 5.2, the proportion of $\beta$-casein in the nonsedimentable fraction decreases, whereas that of $\alpha_{S_{1}}$-casein increases (Dalgleish and Law, 1988). Dalgleish and Law (1988) suggest this difference in behavior may be the greater hydrophobicity of $\beta$-casein or its ability to form larger aggregates as temperature is increased that could sediment when centrifuged. This explains why it was thought that no dissociation of proteins from the casein supramolecule occurs during acidification of milk as long as the temperature is above $25^{\circ} \mathrm{C}$.

Colloidal Protein Reassociations. As discussed by Heertje et al. (1985) and Dalgleish and Law (1988), when $\mathrm{pH}$ of milk approaches $\mathrm{pH} 5.2$, the isoelectric precipitation of $\beta$-casein can occur. Above this $\mathrm{pH}$ it would be expected that $\beta$-casein would be readily released from the casein supramolecules at low temperatures but would then begin to reassociate with the casein supramolecules or aggregate into large polymers and precipitate. Thus, as temperature increases (and there is a corresponding increase in importance of hydrophobic interactions), the return of nonsedimentable casein into large aggregates would occur at higher $\mathrm{pH}$. This is what we observed with larger aggregates of loosely entangled protein occurring at $\mathrm{pH} 5.3$ when the milk was acidified at $40^{\circ} \mathrm{C}$ than at 20 and $30^{\circ} \mathrm{C}$. 
At low temperatures $\left(10^{\circ} \mathrm{C}\right)$ and slow acidification (using 2.0\% GDL, in which it required $175 \mathrm{~min}$ to reach $\mathrm{pH} 5.3$ and 265 min to reach $\mathrm{pH} 5.0$ ), the protein dissociation as shown by the turbidity increase occurred well before aggregation. The turbidity minimum appeared to coincide with a reduction in the loosely entangled protein aggregates and reincorporation of protein back into the casein supramolecules. The turbidity change was smaller with rapid acidification (using 4.0\% GDL in which it required only 60 min to reach pH 5.3 and 85 min to reach $\mathrm{pH} 5.0$ ), suggesting that dissociation from the casein supramolecules is relatively slow and that, as the $\mathrm{pH}$ passes through the $\beta$-casein isoelectric point, reassociation is induced before dissociation is completed.

Gel Formation. In the $40^{\circ} \mathrm{C}$ milk, large spherical colloidal particles were observed throughout the acidification process (see Figures 3 and 8), showing the importance of hydrophobic interactions in maintaining a supramolecular structure (McMahon and Oommen, 2008) even in the absence of calcium phosphate nanoclusters. By pH 5.0, the dissociated proteins appeared to be forming into more densely packed aggregates. Then, by $\mathrm{pH} 4.8$ when a gel had formed, all of the caseins had either reassociated back into the remaining casein supramolecules or coaggregated as part of the 3-dimensional protein network that forms as the milk coagulates. It is, however, unlikely that this reassociation would occur in the same locations from which they dissociated.

Phase 3 of acid gelation of milk thus involves the rapid aggregation of the colloidal casein supramolecules into a gel network as the $\mathrm{pH}$ decreases to 4.8 and lower. This gel network consists of chains of compact spherical particles made of casein supramolecule remnants that remained in colloidal form during acidification, as well as those formed during reassociation of the casein molecules. The nature of the gel is dependent on temperature, with gels at low temperature being composed of smaller particles that form thinner strands and have more crosslinking. At $40^{\circ} \mathrm{C}$, the large size $(\sim 200 \mathrm{~nm}$ diameter) of the aggregating colloidal casein particles (Figure 8A) resulted in a coarse-stranded gel being formed, which is in agreement with Lucey et al. (1997). The importance of hydrophobic liaisons in forming large colloidal particles below pH 5.1 has been shown by Herbert et al. (1999) and consequently, at 10 and $20^{\circ} \mathrm{C}$ (Figure $8 \mathrm{C}$ and $8 \mathrm{D}$ ), the aggregating particles were much smaller $(<100 \mathrm{~nm})$ and a fine-stranded gel was formed.

\section{CONCLUSIONS}

Based on microstructural observations of milk acidified at $10,20,30$, and $40^{\circ} \mathrm{C}$, we propose a 3 -phase model for acid-induced gelation of unheated milk that is temperature-dependent and helps explain the formation of coarse-stranded gels at higher temperatures. Phase 1 involves a temperature-dependent dissociation of proteins from the casein supramolecules, with less protein being released when the milk is warm $\left(40^{\circ} \mathrm{C}\right)$. At low temperatures (e.g., $\left.10^{\circ} \mathrm{C}\right)$, these dissociated proteins are present as loosely entangled aggregates. At $40^{\circ} \mathrm{C}$, there appears to be sufficient hydrophobic interactions to maintain the proteins as (small) spherical colloidal particles (many with diameters $<50 \mathrm{~nm}$ ). As acidification occurs, this dissociation continues, with proteins forming into large, loosely entangled protein aggregates. Such aggregates are nonspherical and do not have the compact nature observed for casein supramolecules, although some are as large as the casein supramolecules and are occasionally attached to the casein supramolecules. Phase 2 of acid gelation occurs between about $\mathrm{pH} 5.3$ and $\mathrm{pH} 4.9$ and involves the loosely entangled proteins forming into more compact colloidal particles. At $40^{\circ} \mathrm{C}$, the loosely entangled aggregates become quite large (up to 200-300 $\mathrm{nm}$ ) whereas, at $10^{\circ} \mathrm{C}$, they are much smaller and have already started to reassociate with the casein supramolecule remnants. Phase 3 involves rapid aggregation of the colloidal casein supramolecules into a gel network as the $\mathrm{pH}$ decreases to 4.8 and lower. This gel network consists of chains of compact spherical particles made of casein supramolecule remnants that remained in colloidal form during acidification, as well as those formed during reassociation of the casein molecules. The nature of the gel is dependent on temperature, with the gel at low temperature being composed of smaller particles that form thinner strands and have more crosslinking. Acid coagulating milk at $10^{\circ} \mathrm{C}$ forms a fine-stranded gel, whereas at $40^{\circ} \mathrm{C}$ a coarse-stranded gel is formed.

\section{ACKNOWLEDGMENTS}

This research was funded by Dairy Management Inc. (Rosemont, IL) and the Utah Agricultural Experiment Station, Utah State University (Logan) and approved as journal paper number 8029 .

\section{REFERENCES}

Alexander, M., and D. G. Dalgleish. 2004. Application of transmission diffusing wave spectroscopy to the study of gelation of milk by acidification and rennet. Colloids Surfaces B: Interfaces 38:8390.

Alleyne, M. C., D. J. McMahon, N. N. Youssef, and S. Hekmat. 1993. An apparatus for a new microcube encapsulation of fluid milk in preparation for transmission electron microscopy. Food Struct. $12: 21-30$.

Banon, S., and J. Hardy. 1991. Study of acid milk coagulation by an optical method using light reflection. J. Dairy Res. 58:75-84.

Banon, S., and J. Hardy. 1992. A colloidal approach of milk acidification by glucono-delta-lactone. J. Dairy Sci. 75:935-941. 
Bringe, N. A., and J. E. Kinsella. 1990. Acidic coagulation of casein supramolecules: Mechanisms inferred from spectrophotometric studies. J. Dairy Res. 57:365-375.

Dalgleish, D. G., M. Alexander, and M. Corredig. 2004a. Studies of the acid gelation of milk using ultrasonic spectroscopy and diffusing wave spectroscopy. Food Hydrocoll. 18:747-755.

Dalgleish, D. G., M. Alexander, and M. Corredig. 2005. Mechanism of acid coagulation of milk studied by a multi-technique approach. Pages 16-25 in Food Colloids: Interactions, Microstructure, and Processing. E. Dickinson, ed. Royal Society of Chemistry, London, UK.

Dalgleish, D. G., and A. J. R. Law. 1988. pH-induced dissociation of bovine casein supramolecules. I. Analysis of liberated caseins. J. Dairy Res. 55:529-538.

Dalgleish, D. G., and A. J. R. Law. 1989. pH-induced dissociation of bovine casein supramolecules. II. Mineral solubilization and its relation to casein release. J. Dairy Res. 56:727-735.

Dalgleish, D. G., P. A. Spagnuolo, and H. D. Goff. 2004b. A possible structure of the casein supramolecule based on high-resolution scanning electron microscopy. Int. Dairy J. 14:1025-1031.

Evanhuis, N., and T. R. de Vries. 1959. The condition of calcium phosphate in milk. Neth. Milk Dairy J. 13:1-15.

Famelart, M. H., J. Tomazewski, M. Piot, and S. Pezennec. 2004. Comprehensive study of acid gelation of heated milk with model protein systems. Int. Dairy J. 14:313-321.

Heertje, I., J. Visser, and P. Smits. 1985. Structure formation in acid milk gels. Food Microstructure 4:267-278.

Herbert, S., A. Riaublanc, B. Bouchet, D. J. Gallant, and E. Dufour. 1999. Fluorescence spectroscopy investigation of acid- or rennetinduced coagulation of milk. J. Dairy Sci. 82:2056-2062.

Kalab, M., D. B. Emmons, and A. G. Sargant. 1976. Milk gel structure V. Microstructure of yoghurt as related to the heating of milk. Milchwissenschaft 31:402-408.

Kalab, M., B. E. Phibbs-Todd, and P. Allan-Wojtas. 1982. Milk gel structure XIII. Rotary shadowing of casein supramolecules for electron microscopy. Milchwissenschaft 37:513-518.

Kauzmann, W. 1959. Some factors in the interpretation of protein denaturation. Adv. Protein Chem. 14:1-63.

Kim, B. Y., and J. E. Kinsella. 1989. Rheological changes during slow acid induced gelation of milk by D-glucono- $\delta$-lactone. J. Food Sci. 54:894-898.

Lucey, J. A. 2001. The relationship between rheological parameters and whey separation in milk gels. Food Hydrocoll. 15:603-608.

Lucey, J. A., and H. Singh. 1998. Formation and physical properties of acid milk gels: A review. Food Res. Int. 30:529-542.

Lucey, J. A., M. Tamehana, H. Singh, and P. A. Munro. 1998. A comparison of the formation, rheological properties and microstructure of acid skim milk gels made with bacterial culture or glucono- $\delta$-lactone. Food Res. Int. 31:147-155.
Lucey, J. A., T. van Vliet, K. Grolle, T. Geurts, and P. Walstra. 1997. Properties of acid casein gels made by acidification with glucono- $\delta$ lactone. 2. Syneresis, permeability and microstructural properties. Int. Dairy J. 7:389-397.

McMahon, D. J., and R. J. Brown. 1982. Evaluation of formagraph for comparing rennet solutions. J. Dairy Sci. 65:1639-1642.

McMahon, D. J., R. J. Brown, and C. A. Ernstrom. 1984. Enzymic coagulation of milk casein supramolecules. J. Dairy Sci. 67:745748

McMahon, D. J., and W. R. McManus. 1998. Rethinking casein supramolecule structure using electron microscopy. J. Dairy Sci. 81:2985-2993.

McMahon, D. J., and B. S. Oommen. 2008. Supramolecular structure of the casein supramolecule. J. Dairy Sci. 91:1709-1721.

Novakovic, P., T. Petrak, J. Kordic, and V. Slacanac. 2000. Application of mathematical models in milk coagulation process during lactic acid fermentation. I. Relation between enzymatic and acidic milk coagulation. Acta Aliment. 29:241-254.

Pierre, A., and G. Brule. 1981. Mineral and protein equilibria between the colloidal and soluble phases of milk at low temperature. J. Dairy Res. 48:417-428.

Qvist, K. B. 1979. Reestablishment of the original rennetability of milk after cooling. 1. The effect of cooling and LTST pasteurization of milk and renneting. Milchwissenschaft 34:467-470.

Roefs, S. P. F. M., P. Walstra, D. G. Dalgleish, and D. S. Horne. 1985. Preliminary note on the change in casein supramolecules caused by acidification. Neth. Milk Dairy J. 39:119-122.

Singh, H., M. S. Roberts, R. A. Munro, and C. T. Teo. 1996. Acidinduced dissociation of casein supramolecules in milk: Effects of heat treatment. J. Dairy Sci. 79:1340-1346.

Tamime, A. Y.. M. Kalab, and G. Davies. 1984. Microstructure of setstyle yoghurt manufactured from cow's milk fortified by various methods. Food Microstructure 3:83-92.

Tranchant, C. C., D. G. Dalgleish, and A. R. Hill. 2001. Different coagulation behaviour of bacteriologically acidified and rennet milk: The importance of fine-tuning acid production and rennet action. Int. Dairy J. 11:483-494.

van Hooydonk, A. C. M., H. G. Hagedoorn, and I. J. Boerrigter. 1986 $\mathrm{pH}$-induced physico-chemical changes of casein supramolecules in milk and their effect on renneting. I. Effect of acidification on physico-chemical properties. Neth. Milk Dairy J. 40:281-296.

Visser, J., A. Minihan, P. Smits, S. B. Tjan, and I. Heertje. 1986. Effects of $\mathrm{pH}$ and temperature on the milk salt system. Neth. Milk Dairy J. 40:351-368.

Vreeman, H. J., B. W. van Markwijk, and P. Both. 1989. The structure of casein supramolecules between $\mathrm{pH} 5.5$ and 6.7 as determined by light-scattering, electron microscopy and voluminosity experiments. J. Dairy Res. 56:463-470. 